\title{
Communication
}

[Comunicação]

\section{Isolation and characterizaton of Edwardsiella tarda from pacu Myleus micans}

\author{
[Isolamento e caracterização de Edwardsiella tarda em pacu Myleus micans] \\ L.C. Lima ${ }^{1}$, A.A. Fernandes ${ }^{1}$, A.A.P. Costa ${ }^{2}$, F.O. Velasco ${ }^{2}$, R.C. Leite ${ }^{1}$, J.L. Hackett ${ }^{3}$ \\ ${ }^{1}$ Escola de Veterinária - UFMG \\ Caixa Postal 567 \\ 30123-970 - Belo Horizonte, MG \\ ${ }^{2}$ Aluno de graduação - EV-UFMG - Belo Horizonte, MG \\ ${ }^{3}$ Fisheries and Environmental Management Services - Victoria, BC, Canada
}

In January 2005, significant fish mortality occurred in several species in the São Francisco river which extended along 2006. The mortality in fish stocks in this Brazilian river basin is of great concern since fishery is the main source of economic income for the local communities and many of the affected species are of great economic value. In order to elucidate the causes of the fish kill, a series of physical, chemical, toxicological, and microbiological analysis were carried out. Among the bacteria found in the species sampled, it was isolated Edwardsiella tarda from pacu Myleus micans.

E. tarda, a member of the family Enterobacteriaceae, is the causative agent of septicemia in a variety of fish species, being frequently isolated from Japanese flounder Paralichthys olivaceous (Miwa and Nobuhiro, 2000), eels Anguilla japonica, and catfish Ictalurus punctatus (Inglis et al., 2001). In Brazil, E. tarda was isolated from farmed rainbow trout Oncorhynchus mykiss (Alexandrino et al., 1999). Although it is commonly classified as opportunistic, E. tarda is considered a serious pathogen of fish. This bacterium is also important due its zoonotic aspects. Infected fish processed for human consumption is a source of gastroenteritis and meningitis (Janda and Abbot, 1993; Inglis et al., 2001; Muratori et al. 2001).
A minimum of five alive and moribund fish were collected from the main zones of mortality. After clinical examination, kidney samples were aseptically collected, streaked onto blood agar and on brain heart infusion agar (BHI). The plates were brought to the laboratory for colonies identification. Sub samples were grown onto BHI and blood agars and pure individualized colonies were streaked onto McConkey (MC) and Salmonela-Shigella (SS) agars and incubated at $30^{\circ} \mathrm{C}$, for $24-48 \mathrm{~h}$. Et-LIS antimicrobial susceptibility patterns were determined by the disk diffusion method using Muller-Hinton agar. The following drugs were tested: erythromycin, ampicillin, penicillin, tetracycline, enrofloxacin, sulfazotrin, neomycin, amoxillin, streptomycin, ceftiofur, gentamycin, and florfenicol. Virulence characteristics of Et-LIS were assessed by challenging two tropical species, tilapia Oreochromis spp. and carp Cyprinus carpio. The fish were inoculated with $2 \mathrm{ml}$ of bacterial solution prepared according pattern 2 of McFarland standards. The individuals were kept without feeding and isolated in aquaria until die. The control group was injected with $2 \mathrm{ml}$ of saline solution and sacrificed to permit comparisons with the challenged individuals. Portions of kidneys, liver, and celomatic exudates were aseptically removed and streaked in SS agar to confirm the infection of E. tarda.

Recebido em 23 de fevereiro de 2007

Aceito em 18 de dezembro de 2007

E-mail: lucolima@netscape.net 
On BHI agar plates, Et-LIS colonies were small (1 $\mathrm{mm}$ diameter), transparent, and punctate. Colonies on SS agar varied from $1-3 \mathrm{~mm}$ diameter and showed small black centers to predominantly black colonies indicating $\mathrm{H}_{2} \mathrm{~S}$ production. While presumptive identification revealed small Gram negative rods, biochemical characterizations, in triplicate, permitted the identification of the isolate as Edwardsiella tarda (Table 1). To confirm the identification by conventional methods, a rapid diagnostic kit (Bactray system $)^{1}$ was also used. Run in duplicate, the kit identified E. tarda at $99.9 \%$ confidence level.

Table 1. Biochemical profile of Edwardsiella tarda, Et-LIS, isolated from kidney of pacu Myleus micans

\begin{tabular}{lclc}
\hline Characteristic & & Characteristic & + \\
\hline Gram stain & - & Glucose & - \\
Catalase & + & Arabinose & - \\
Cytochrome oxidase & - & Lactose & - \\
Voges-Proskauker & - & Trehalose & - \\
Lysine descarboxylase & + & Inositol & - \\
Ornithin descarboxylase & + & Salicin & + \\
Citrate, Simmons & - & & - \\
Oxidative/Fermentative & ++ & Fructose & - \\
Sulphide & + & Sucrose & - \\
Indole & + & Adonitol & $\mathrm{K} / \mathrm{AG}$ \\
Motility & + & Dulcitol & + \\
Esculin hydrolysis & - & Triple Sugar Iron agar $*$ & $\mathrm{NaCl}$ \\
Urease & - & Growth in BHI with $3 \% \mathrm{NaC}$ & \\
\hline
\end{tabular}

$\mathrm{K}=$ alkaline or no reaction, $\mathrm{A}=$ acid production, $\mathrm{G}=$ gas production.

In antimicrobial susceptibility assay, Et-LIS tested sensitive to all the 12 drugs used, except for erythromycin (resistant) and penicillin (intermediate). According to the literature, $E$. tarda is sensitive to a wide variety of antimicrobials (Janda and Abbot, 1993) and, therefore, nearly any approved drug can be used to combat the infection. In challenged fish, EtLIS pure cultures were recovered from celomatic exudates and from kidney. Tilapias challenged were found dead within $24 \mathrm{~h}$ after exposure, while the carps lived for $72 \mathrm{~h}$. Both species showed similar infection signs like reddening of fins, opercula, and anal region. Also, tilapias and carps showed corneal opacity, body ulcers, abdominal swelling, a generalized internal hyperemia and organs enlarged and hemorrhagic. Similar symptoms were found in infected rainbow trout reared in intensive flow-through systems (Alexandrino et al., 1999). Clinical signs of E. tarda infection may slightly differ from fish species to species. Experimentally infected, channel catfish exhibited hemorrhages in the visceral organs, however none of the usual external signs found among fish with natural infections were noted in experimentally inoculated fish (Inglis et al., 2000). Together with other genus like Aeromonas, isolated from additional fish species sampled with the infected pacu, it is suggested that E. tarda might have had a role in the mortality occurred in the São Francisco river system. Although Et-LIS showed to be susceptible to a relatively great range of drugs, its isolate infection can be fatal to other tropical fish species. Et-LIS also seems to be more fulminating to common carp than tilapia.

Keywords: fish, pacu, Myleus micans, Edwardsiella tarda, Sao Francisco basin

\section{RESUMO}

Investigaram-se as causas da mortalidade de peixes ocorrida em janeiro de 2005 na bacia do Rio São Francisco, Brasil. Edwardsiella tarda foi isolada dos rins de pacu Myleus micans. O isolado, denominado Et-LIS, caracterizado por bastonetes Gram negativos móveis, foi identificado por testes bioquímicos e confirmado pelo kit comercial Bactray. A susceptibilidade a 10 drogas das 12 testadas foi determinada

${ }^{1}$ Laborclin - Pinhais, PR ,Brazil. 
pelo método de difusão de discos, enquanto as características de virulência foram avaliadas mediante inoculação experimental em Cyprinus carpio e em Oreochromis spp. Ambas as espécies desafiadas apresentaram sinais compativeis com infecção por E. tarda. As tilápias (Oreochromis spp.) morreram $48 h$ após a inoculação, enquanto as carpas (Cyprinus carpio) sobreviveram por $72 \mathrm{~h}$. Este é o primeiro relato da ocorrência de E. tarda em pacu.

Palavras-chave: peixe, pacu, Myleus micans, Edwardsiella tarda, bacia do São Francisco

\section{REFERENCES}

ALEXANDRINO, A.C.; OKUMURA, M.P.M.; BALDASSI, L. et al. Ocorrência de infecção por Edwardsiella tarda em truta arco-iris Oncorhynchus mykiss em cultivo intensivo. Bol. Inst. Pesca, v.25, p.121-123, 1999.

INGLIS, V.; ROBERTS, R.J.; BROMAGE, N.R. (Eds.). Bacterial diseases of fish. London: Blackwell Scientific, 2001.312p.

JANDA, J.M.; ABBOT, S.L. Infections associated with the genus Edwardsiella: the role of Edwardsiella tarda in human disease. Clin. Infect. Dis., v.17, p.742-748, 1993.

MIWA, S.; NOBUHIRO, M. Infection with Edwardsiella tarda causes hypertrophy of liver cells in the Japanese flounder Paralichthys olivaceous. Dis. Aquat. Organ., v.42, p.227-231, 2000.

MURATORI, M.C.S.; MARTINS, N.E.; PEIXOTO, M.T.D. et al. Edwardsiella septicemia mortality in tilapia-integrated with pig in fish farming. Arq. Bras. Med. Vet. Zootec., v.53, p.658-662, 2001. 